\section{Yield Increases in Burrowing Nematode- infested Anthurium with Fluopyram and Trifloxystrobin Applications}

\author{
Roxana Myers ${ }^{1}$, Brian Bushe ${ }^{2}$, Cathy Mello ${ }^{1}$, Joanne Lichty ${ }^{3}$, \\ Arnold Hara ${ }^{3}$, Koon-Hui Wang ${ }^{4}$, and Brent Sipes ${ }^{4}$
}

AdDitional INDEX wORDs. Anthurium andraeanum, anthurium decline, burrowing nematode, fluopyram, nematode management, Radopholus similis

SUMMARY. Burrowing nematode (Radopholus similis) causes severe stunting and yield reduction in anthurium (Anthurium andraeanum) cut flower production. Two field trials were conducted at commercial grower farms to test the efficacy of fluopyram or fluopyram + trifloxystrobin for managing burrowing nematodes. Nematode population densities in roots and cinder media were evaluated during the trial in addition to cut flower yield and canopy cover. In the first trial, the nematode population in roots was reduced by $57 \%$ after two applications of fluopyram 3 months apart. As plant health improved, the increasing anthurium root weight supported higher nematode populations. After 14 months, fluopyram-treated plots had $43 \%$ more green canopy cover and a $53 \%$ increase in flower production compared with the untreated control plots. At a second location, population densities of burrowing nematode were reduced in roots after one application of fluopyram + trifloxystrobin and remained low with quarterly applications. Nematode populations were initially reduced in fluopyram-treated plots followed by a resurgence as demonstrated in the other trial. Ten months after the initial treatment, flower yield was greater in fluopyram + trifloxystrobin-treated plots with more large and extra-large flowers produced. Canopy cover was $45 \%$ and $22 \%$ greater with fluopyram + trifloxystrobin and fluopyram applications, respectively. Fluopyram shows potential for management of burrowing nematodes in anthurium by improving plant vigor and cut flower production.

$\mathrm{B}$ urrowing nematode (Radopholus similis) is a major pest of many important agricultural

Received for publication 13 May 2020. Accepted for publication 3 Aug. 2020.

Published online 28 August 2020

${ }^{1}$ U.S. Department of Agriculture, Agricultural Research Service, Daniel K. Inouye U.S. Pacific Basin Agricultural Research Center, 64 Nowelo Street, Hilo, HI 96720

${ }^{2}$ Department of Plant and Environmental Protection Sciences, University of Hawaii at Manoa, 875 Komohana Street, Hilo, HI 96720

${ }^{3}$ Department of Tropical Plant and Soil Sciences, University of Hawaii at Manoa, 875 Komohana Street, Hilo, HI 96720

${ }^{4}$ Department of Plant and Environmental Protection Sciences, University of Hawaii at Manoa, 3190 Maile Way, Honolulu, HI 96822

We thank our grower cooperators Floral Resources and Pacific Floral Exchange, as well as Kimberly Escobar, Jon Katada, Ruth Niino-DuPonte, and Lenny Fujimoto for their assistance.

Mention of trade names or commercial products in this publication is solely for the purpose of providing specific information and does not imply recommendation or endorsement by the U.S. Department of Agriculture. U.S. Department of Agriculture is an equal opportunity provider and employer.

R.M. is the corresponding author. E-mail: roxana. myers@usda.gov.

This is an open access article distributed under the CC BY-NC-ND license (https://creativecommons.org/ licenses/by-nc-nd/4.0/).

https://doi.org/10.21273/HORTTECH04648-20 crops throughout subtropical and tropical regions. An endoparasitic migratory nematode, burrowing nematode spends its life inside the root where it feeds and reproduces (Duncan and Moens, 2006). Commonly known for its infestations on citrus (Citrus sp.) and banana (Musa acuminata), burrowing nematode is a pest of quarantine importance (Class A in California, A2 in Europe) that results in strict regulations on potted plant exports from infested regions.

In Hawaii, burrowing nematode causes anthurium decline with limited options for management (Aragaki et al., 1984). Dark lesions visible on anthurium (Anthurium andraeanum) roots during the initial stages of infestation lead to root rot, blackening, and eventual destruction of the root system. The overall plant height as well as leaf development are retarded by infestations of burrowing nematode (Sipes and Lichty, 2002). Fewer flowers are produced because flowers are subtended by each new leaf. Commercial cultivars average less than six leaves per flowers per year per plant in noninfested conditions. Infested plants become severely stunted, resulting in yield reductions of up to $50 \%$ (Sipes and Lichty, 2002). Screening of commercial anthurium cultivars and hybrids in Hawaii revealed no obvious resistance to burrowing nematode (Wang et al., 1997).

Anthuriums are the most important cut flower in the Hawaiian floriculture industry with a farm gate value of $\$ 2.7$ million (U.S. Department of Agriculture and Hawaii Department of Agriculture, 2019). Even so, maximum production is not being achieved due to yield reductions and high production costs associated with bacterial blight and plant-parasitic nematodes. Historically commercial anthurium growers have treated nematode-infested fields with fenamiphos, but since its voluntary removal from the market (U.S. Environmental Protection Agency, 2011), no postplant nematicides have been demonstrated effective in managing anthurium decline.

Fluopyram was first introduced as a fungicide in 2007 and later as a nematicide in 2014. Due to the efficacy of this chemical, significant increases in yield and quality were demonstrated in field tests with several agriculturally important crops (Jeschke, 2016). Fluopyram inhibits the mitochondrial respiratory chain in plant-parasitic nematodes, resulting 
in a depletion of energy and immobilization of the organism. In-furrow applications of fluopyram combined with imidacloprid reduced root-knot (Meloidogyne incognita) and reniform nematode (Rotylenchulus reniformis) population densities in cotton (Gossypium sp.) plantings (Lawrence et al., 2014). Fluopyram suppressed sting nematodes (Belonolaimus longicaudatus) in turf with effects being observed for 6 to 8 months after the final application (Crow et al., 2017).

The systemic nature of fluopyram allows it to penetrate the roots and target migratory endoparasitic nematodes. In tea (Camellia sinensis) plantations, fluopyram at 600 to $800 \mathrm{~g} \cdot \mathrm{ha}^{-1}$ was found to be effective for control of burrowing nematode (Mohotti et al., 2018 ). Yield increases of $45 \%$ were observed with fluopyram treatments in banana infested with burrowing and banana root nematodes [Pratylenchus coffeae (Vawa et al., 2019)].

Fluopyram could be useful for limiting damage caused by plant-parasitic nematodes in anthurium cut flower production. This research focuses on examining the potential of two fluopyram formulations, Indemnify and Luna Sensation (Bayer CropScience, Research Triangle Park, NC) against burrowing nematode in field grown anthurium. Indemnify is registered as a fungicide with nematicidal properties on turfgrass and contains only the active ingredient fluopyram $(34.5 \%)$. Luna Sensation contains fluopyram $(21.4 \%)$ and trifloxystrobin $(21.4 \%)$ as active ingredients and is registered as a fungicide for use on fruit and vegetable crops. The specific objectives of this study were to assess their efficacy in 1) reducing burrowing nematode populations and 2) increasing cut flower yields.

\section{Materials and methods}

Trial 1. A field trial was conducted at a commercial anthurium farm in Hilo, HI, with a 2-year-old established planting of 'Starlight' anthurium inside a shadehouse with $78 \%$ shade. Plants were growing in beds of volcanic cinder medium on the ground, a typical growing medium for anthurium farmers in Hawaii. All plants were stunted from a natural infestation of burrowing nematode before the initiating the experiment. Plants received natural rainfall of $\approx 380 \mathrm{~cm}$ per year and were supplemented by overhead irrigation during drought. Average temperature in the shadehouse was $23^{\circ} \mathrm{C}$ with $90 \%$ average relative humidity. The two treatments evaluated in the field trial were a fluopyram application (Indemnify) and an untreated control. Each treatment plot was $15 \times 4 \mathrm{ft}$ and contained 52 plants. Treatment plots were replicated four times and arranged in a randomized complete block design. Two border rows of anthurium were placed in between treated and untreated plots.

The trial was initiated on $20 \mathrm{Apr}$. 2017 and concluded on 20 July 2018. Five applications were administered during that time. The treated plots were sprayed with fluopyram alone at a rate of $0.14 \mathrm{fl} \mathrm{oz} / 1000 \mathrm{ft}^{2}$. The application was applied to the foliage until runoff and repeated once every 3 months. The untreated control was sprayed with tap water.

Nematode sampling was conducted before the first fluopyram application and every month thereafter for 14 months. Anthurium roots and cinder from the rhizosphere were collected from six plants per plot and composited. At the laboratory, all roots were separated from the cinder media. Subsamples of $\approx 10 \mathrm{~g}$ of roots (wet weight) and $100 \mathrm{~cm}^{3}$ of cinder were taken from each sample. Roots or cinder were placed individually on Baermann funnels for $72 \mathrm{~h}$ (Walker and Wilson, 1960). Nematodes were concentrated on a $20-\mu \mathrm{m}$ pore sieve, collected in $25 \mathrm{~mL}$ of tap water, and counted under an inverted light microscope (DMlL; Leica, Wetzlar, Germany).

Anthurium cut flowers were harvested weekly and graded according to industry standards by the grower as corsage (3.5-3.9 inches), small (4.0-4.5 inches), medium (4.5-4.9 inches), and large (5.0-5.9 inches) width. At the termination of the trial, 14 months after the initial fluopyram application, photographs were taken of three subsections of each plot measuring $4 \times 5 \mathrm{ft}$ from a horizontal plane $5 \mathrm{ft}$ above the ground. Using the imaging application Canopeo (Oklahoma State University, Stillwater, OK), percent canopy cover was quantified and compared among treatments (Patrignani and Ochsner, 2015).

Trial 2. A field trial was conducted at a second commercial anthurium farm in Pahoa, $\mathrm{HI}$, commencing on 2 Aug. 2017 and ending on 20 July 2018 with four applications administered during the trial. Treatments were tested on 'Midori' anthurium planted 18 months before the initiation of the trial. Growing conditions were as described in Trial 1. Plants were naturally infested with burrowing nematode. Each plot contained 60 plants with four plots per treatment. Treatment plots were divided by borders of six rows of anthurium plants.

Treatments consisted of fluopyram at a rate of $0.14 \mathrm{fl} \mathrm{oz} / 1000$ $\mathrm{ft}^{2}$, fluopyram + trifloxystrobin at $0.30 \mathrm{fl} \mathrm{oz} / 1000 \mathrm{ft}^{2}$ of each, and an untreated water control. The products were applied foliarly, and applications were made by spraying to runoff once every 3 months.

Nematode sampling was performed before the first treatment to assess initial nematode population densities, and sampling was conducted every 3 months thereafter immediately before fluopyram applications. Root and cinder samples were collected from each plot and processed as described earlier.

Weekly harvesting and grading of cut flowers were carried out by the farmer as described in Trial 1 with the addition of an extra-large $(\geq 6.0$ inches width) standard. Photographs were obtained, and the plant canopy was quantified using Canopeo as previously described.

Statistical analysis. Nematode data from each trial were subjected to time $\times$ treatment analysis of variance (ANOVA). When an interaction was significant, treatments were analyzed by time sections. Otherwise data were subjected to repeated measure over time using PROC GLM in SAS (version 9.4; SAS Institute, Cary, NC). Anthurium yield data and plant canopy cover were subjected to one-way ANOVA. All means were separated by least significant difference.

\section{Results}

Trial 1. Monthly monitoring of burrowing nematode population densities from anthurium roots revealed lower nematode densities in fluopyram-treated plots compared with untreated control plots during the first 6 months after initial nematicide application $(P \leq 0.01)$ with a population reduction of $57 \%$ compared with the 
Table 1. Population of burrowing nematode recovered from 'Starlight' anthurium treated with fluopyram at $0.14 \mathrm{fl} \mathrm{oz} / 1000 \mathrm{ft}^{2}\left(0.446 \mathrm{~L} \cdot \mathrm{ha}^{-1}\right)$.

\begin{tabular}{|c|c|c|c|c|}
\hline \multirow[b]{3}{*}{ Treatment } & \multicolumn{4}{|c|}{ Burrowing nematodes (no.) } \\
\hline & \multicolumn{2}{|c|}{ 1-6 mo. after first application } & \multicolumn{2}{|c|}{ 7-14 mo. after first application } \\
\hline & $\begin{array}{c}\text { Roots } \\
(\text { no. } / 10 \mathrm{~g})^{\mathrm{z}}\end{array}$ & $\begin{array}{c}\text { Cinder } \\
\left(\text { no. } / 100 \mathrm{~cm}^{3}\right)^{\mathrm{z}}\end{array}$ & $\begin{array}{c}\text { Roots } \\
(\text { no. } / 10 \mathrm{~g})\end{array}$ & $\begin{array}{c}\text { Cinder } \\
\left(\text { no. } / 100 \mathrm{~cm}^{3}\right) \\
\end{array}$ \\
\hline Fluopyram & $30 b^{y}$ & $22 \mathrm{a}$ & $36 \mathrm{a}$ & $38 \mathrm{a}$ \\
\hline Untreated & $68 \mathrm{a}$ & $34 \mathrm{a}$ & $29 \mathrm{a}$ & $24 \mathrm{~b}$ \\
\hline
\end{tabular}

${ }^{\mathrm{z}} 1$ nematode $/ 10 \mathrm{~g}=45.3592$ nematodes $/ \mathrm{lb}, 1$ nematode $/ 100 \mathrm{~cm}^{3}=283.1684$ nematodes $/ \mathrm{ft}^{3}$.

${ }^{\mathrm{y}}$ Treatments with the same letter within a column are not different $(P>0.05)$ according to least significant difference test.

Table 2. 'Starlight' anthurium cut flowers harvested over 14 mo. in plots treated with fluopyram at $0.14 \mathrm{fl} \mathrm{oz} / 1000 \mathrm{ft}^{2}\left(0.446 \mathrm{~L} \cdot \mathrm{ha}^{-1}\right)$.

\begin{tabular}{lccccr}
\hline & \multicolumn{5}{c}{ Flower grades $^{\mathrm{z}}$} \\
\cline { 2 - 5 } Treatment & Corsage & Small & Medium & Large & Total \\
\hline Fluopyram & $902 \mathrm{a}^{\mathrm{y}}$ & $471 \mathrm{a}$ & $219 \mathrm{a}$ & $36 \mathrm{a}$ & $1628 \mathrm{a}$ \\
Untreated & $679 \mathrm{~b}$ & $295 \mathrm{~b}$ & $89 \mathrm{~b}$ & $2 \mathrm{a}$ & $1065 \mathrm{~b}$ \\
\hline
\end{tabular}

${ }^{\mathrm{z}}$ Anthurium spathes are measured by width to determine flower grade: corsage $=3.5-3.9$ inches, small $=4.0-4.5$ inches, medium $=4.5-4.9$ inches, large $=5.0-5.9$ inches; 1 inch $=2.54 \mathrm{~cm}$.

'Treatments with the same letter within a column are not statistically different according to least significant difference test $(P>0.005)$

Table 3. Population of burrowing nematode recovered from 'Midori' anthurium treated with fluopyram + trifloxystrobin $\left(0.30 \mathrm{fl} \mathrm{oz} / 1000 \mathrm{ft}^{2}\right.$ of each $)$ or fluopyram $\left(0.14 \mathrm{fl} \mathrm{oz} / 1000 \mathrm{ft}^{2}\right)$ over a $12-$ mo. period. ${ }^{\mathrm{z}}$

\begin{tabular}{lcc}
\hline & \multicolumn{2}{c}{ Burrowing nematodes (no.) } \\
\cline { 2 - 3 } Treatment & Root $(\mathbf{n o} / \mathbf{1 0 ~ g})^{\mathrm{z}}$ & Cinder $\left(\mathbf{n o .} / \mathbf{1 0 0 \mathbf { ~ c m } ^ { \mathbf { 3 } } ) ^ { \mathbf { z } }}\right.$ \\
\hline Fluopyram + trifloxystrobin & $3 \mathrm{~b}^{\mathrm{y}}$ & $5 \mathrm{a}$ \\
Fluopyram & $26 \mathrm{ab}$ & $18 \mathrm{a}$ \\
Untreated & $32 \mathrm{a}$ & $21 \mathrm{a}$ \\
\hline
\end{tabular}

${ }^{\mathrm{z}} 1 \mathrm{fl} \mathrm{oz} / 1000 \mathrm{ft}^{2}=3.1833 \mathrm{~L} \cdot \mathrm{ha}^{-1}, \mathrm{l}$ nematode $/ 10 \mathrm{~g}=45.3592$ nematodes $/ \mathrm{lb}, \mathrm{l}$ nematode $/ 100 \mathrm{~cm}^{3}=283.1684$ nematodes $/ \mathrm{ft}^{3}$.

${ }^{\mathrm{x}}$ Treatments with the same letter within a column are not different $(P>0.05)$ according to least significant difference test.

control (Table 1). In the following 8 months, no differences in the number of nematodes extracted from roots were observed between treatments $(P \geq 0.05)$. No differences in population densities of burrowing nematode were detected in cinder during the first 6 months of the trial $(P \geq 0.05)$. More nematodes were recovered from fluopyram-treated plots in the remaining months $(P \leq 0.05)$.

After two fluopyram applications, weekly cut flower yield improved and began to increase with subsequent applications. Over the 14-month trial, fluopyram-treated plots produced $53 \%$ more cut flower stems than untreated plots $[1628$ vs. 1065 stems $(P \leq$ $0.01)]$. The size of harvested flowers also improved with $145 \%$ more medium-sized and $1700 \%$ more large flowers from treated plots (Table 2).

Plant vigor at the end of the trial indicated a $43 \%$ greater percentage of green canopy cover in fluopyramtreated vs. untreated plots $(P \leq$ $0.01)$. More robust roots were observed on the surface of cinder beds along with an increase in foliage production in plots treated with fluopyram. Root sampling was more efficient in treated plots due to the availability of additional roots per plant.

Trial 2. Plots treated with fluopyram + trifloxystrobin started with the highest nematode population densities in the roots before fluopyram applications. The results showed that after one treatment, the number of burrowing nematodes in the roots dropped lower than all other treatments and remained low with quarterly applications $[P \leq 0.01$ (Table 3 )]. Nematode populations in the roots were initially reduced in fluopyramtreated plots followed by an increase as demonstrated in Trial 1 . Because no interaction between sampling data and fluopyram treatments were found in ANOVA, population densities of burrowing nematode in roots over a 12 -month period were combined in a repeated-measure analysis. The number of burrowing nematodes in roots differed only among fluopyram + trifloxystrobin-treated plots and untreated controls $(P \leq 0.05)$. No differences in burrowing nematode population densities were detected among treatments in cinder $(P \geq$ 0.05 ).

Over the 10 months that yield data were taken, no difference was observed in total flower yield between fluopyram-treated plots and untreated control plots $(P \geq 0.05)$. An increase in flower size was observed with more extra-large flowers harvested in fluopyram + trifloxystrobin plots compared with untreated controls $(P \leq 0.05)$. With increasing applications, yields in treated plots improved. During the last month of data collection, fluopyram + trifloxystrobin-treated plots had a higher overall yield than untreated plots $(P \leq 0.01)$ and a greater number of large $(P \leq 0.01)$ and extra-large flowers $(P \leq 0.05)$ (Table 4).

Plant vigor increased with both fluopyram applications $[P \leq 0.01$ (Fig. 1)]. Fluopyram + trifloxystrobin-treated plots had greater green canopy cover $(86 \%)$ than fluopyram and the untreated control. Fluopyram-treated plots had more plant growth than untreated plots with $72 \%$ green canopy cover compared with $59 \%$ in the control.

\section{Discussion}

Quarterly fluopyram and fluopyram + trifloxystrobin applications to field grown anthurium initially decreased burrowing nematode populations in the roots and increased canopy cover, flower size, and flower yield over time. A marketable increase in cut flower production was observed in 'Starlight' (Trial 1 ) after just two applications of fluopyram. In Trial 2, quarterly applications of fluopyram + trifloxystrobin resulted in increased cut flower size and yield. Plants treated with fluopyram in the second trial also demonstrated a yield and size increase, although this was not statistically different from the other treatments. Some inconsistencies existed in the yield data with 
Table 4. 'Midori' anthurium cut flowers harvested during month 10 after four applications of fluopyram + trifloxystrobin $\left(0.30 \mathrm{fl} \mathrm{oz} / 1000 \mathrm{ft}^{2}\right.$ of each $)$ or fluopyram $\left(0.14 \mathrm{fl} \mathrm{oz} / 1000 \mathrm{ft}^{2}\right) .^{\mathrm{z}}$

\begin{tabular}{lcccccc}
\hline & \multicolumn{5}{c}{ Flower grades $^{\mathrm{y}}$} \\
\cline { 2 - 6 } Treatment & Corsage & Small & Medium & Large & Extra large & Total \\
\hline Fluopyram + trifloxystrobin & $3 \mathrm{a}^{\mathrm{x}}$ & $15 \mathrm{a}$ & $29 \mathrm{a}$ & $29 \mathrm{a}$ & $21 \mathrm{a}$ & $97 \mathrm{a}$ \\
Fluopyram & $6 \mathrm{a}$ & $23 \mathrm{a}$ & $25 \mathrm{a}$ & $17 \mathrm{ab}$ & $8 \mathrm{ab}$ & $79 \mathrm{ab}$ \\
Untreated & $6 \mathrm{a}$ & $22 \mathrm{a}$ & $19 \mathrm{a}$ & $7 \mathrm{~b}$ & $0 \mathrm{~b}$ & $54 \mathrm{~b}$ \\
\hline
\end{tabular}

${ }^{\mathrm{z}} \mathrm{l} \mathrm{floz} / \mathrm{l} 000 \mathrm{ft}^{2}=3.1833 \mathrm{~L} \cdot \mathrm{ha}^{-1}$

${ }^{y}$ Anthurium spathes are measured by width to determine flower grade: corsage $=3.5-3.9$ inches, small $=4.0-4.5$ inches, medium $=4.5-4.9$ inches, large $=5.0-5.9$ inches, extra large $\geq 6.0$ inches; 1 inch $=2.54 \mathrm{~cm}$.

${ }^{\mathrm{x}}$ Treatments with the same letter within a column are not different $(P>0.05)$ according to least significant difference test.
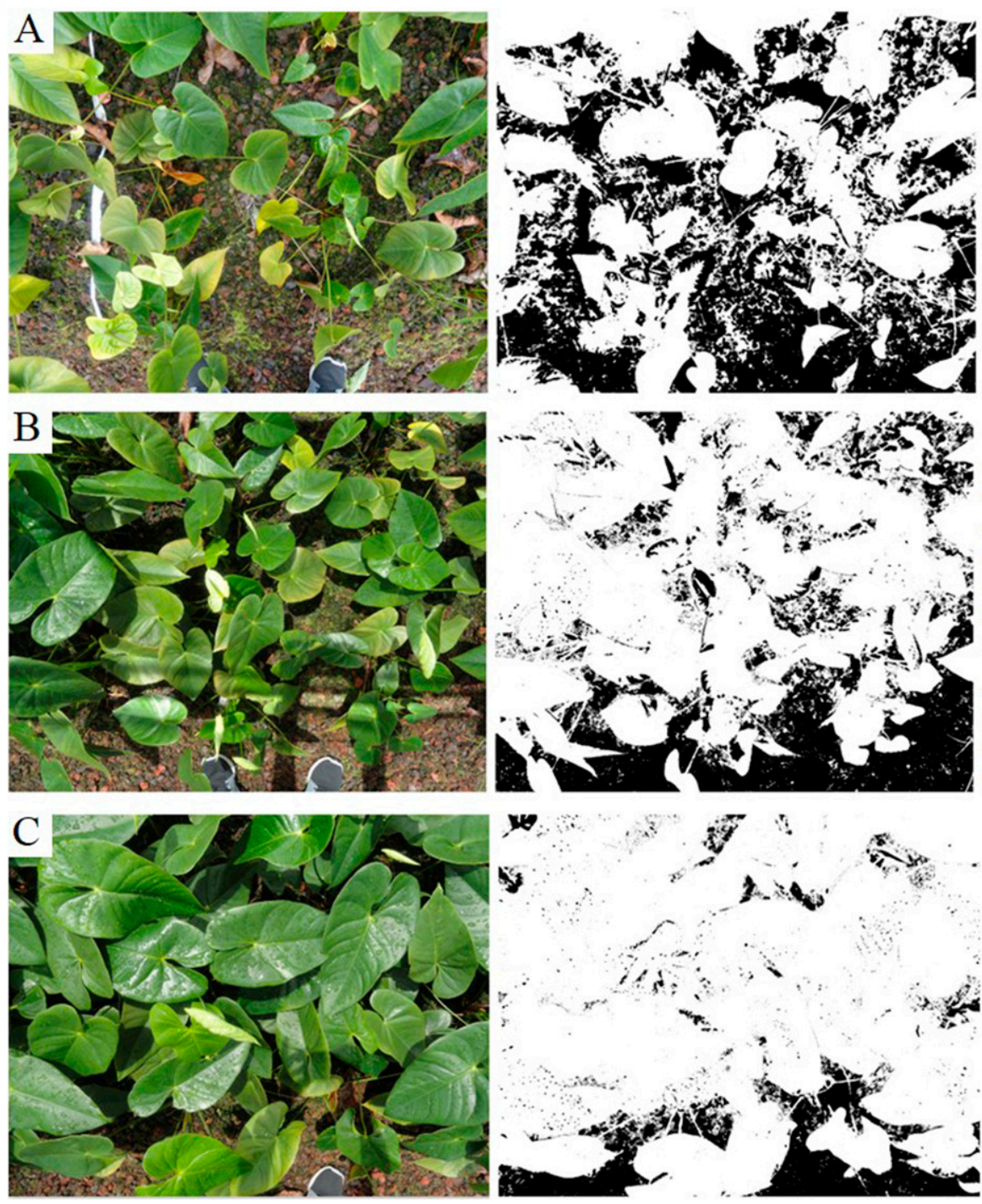

Fig. 1. Green canopy cover (on the left) measured using imaging analysis (on the right) of 'Midori' anthurium in (A) untreated, (B) treated with fluopyram at 0.14 $\mathrm{fl} \mathrm{oz} / 1000 \mathrm{ft}^{2}\left(0.446 \mathrm{~L} \cdot \mathrm{ha}^{-1}\right)$, and $(\mathrm{C})$ treated with fluopyram + trifloxystrobin at $0.30 \mathrm{fl} \mathrm{oz} / 1000 \mathrm{ft}^{2}\left(0.955 \mathrm{~L} \cdot \mathrm{ha}^{-1}\right)$ of each.

regard to the performance of fluopyram between Trials 1 and 2, which could be attributed to the nematode tolerance/susceptibility of the two cultivars. Whereas susceptibility of 'Starlight' to burrowing nematode has not been assessed, 'Midori' used in Trial 2 demonstrated moderate tolerance to burrowing nematode among 17 commercially grown cultivars evaluated in a bioassay (Wang et al., 1998).

Evaluating burrowing nematode populations in the cinder was not a good indicator of nematicide efficacy in this study due to the endoparasitic nature of the nematode. Taking samples from cinder, which has larger pore spaces than regular soil, even in close proximity to the root system showed no significance among treatments in both trials. Extracting burrowing nematodes from roots, however, was useful in detecting the nematode-suppressive effects of fluopyram.

The first two applications of fluopyram caused a reduction in the population densities of burrowing nematode in roots in both trials. After the third application, the trend began to reverse as plants in treated plots exhibited increasing plant vigor and could support higher nematode populations. At the same time, roots of untreated plants became increasingly necrotic with limited living tissue to support nematode feeding. In other anthurium studies, fewer roots also resulted in lower nematode reproduction (Sipes and Lichty, 2002; Wang et al., 1997).

Initial symptoms of burrowing nematode infestations are necrotic root lesions, which are accelerated into extensive root rots by secondary pathogens and saprophytes (Uchida et al., 2003). Although not identified or evaluated in this study, parasitic oomycetes (Pythium) and plant-parasitic fungi (Rhizoctonia solani and Calonectria crotalariae) have previously been isolated from anthurium roots at the University of Hawaii's College of Tropical Agriculture and Human Resources Agricultural Diagnostic Service Center (B. Bushe, unpublished data). The fungicidal effects of fluopyram and trifloxystrobin in this trial could have caused mortality to these fungal organisms and delayed the progression of root decomposition. Although pathogenic fungi were found in advanced stages of root rot in declining plants, applications of fungicide alone did not reduce disease severity (Aragaki et al., 1984). Aragaki et al. (1984) also reported that fungi were not recovered from young necrotic lesions, suggesting that burrowing nematodes 
were the cause of initiating disease symptoms.

Whether applied as a nematicide or a fungicide, fluopyram appeared to improve the plant health and yield of anthurium in the presence of burrowing nematode. Although nematode populations in the media were not representative of its nematode-suppressive effects, plant vigor, flower size, and cut flower yield were significantly improved with fluopyram and fluopyram + trifloxystrobin applications. Fluopyram appears to have potential in mitigating the damage caused by burrowing nematodes and shows promise as a management tool in anthurium field production.

\section{Literature cited}

Aragaki, M., W.J. Apt, R.K. Kunimoto, W.H. Ko, and J.Y. Uchida. 1984. Nature and control of anthurium decline. Plant Dis. Rep. 68:509-511.

Crow, W.T., J.O. Becker, and J.H. Baird. 2017. New golf course nematicides. 13 July 2020. <https://www.gcsaa.org/ $\mathrm{gcm} / 2017 / \mathrm{july} / \mathrm{new}$-golf-coursenematicides $>$.

Duncan, L.W. and M. Moens. 2006. Migratory endoparasitic nematodes, p. 123-152. In: R.N. Perry and M. Moens (eds.). Plant nematology. CABI, Wallingford, U.K.

Jeschke, P. 2016. Progress of modern agricultural chemistry and future prospects. Pest Mgt. Sci. 72:433-455.
Lawrence, K., G. Lawrence, T. Faske, C. Overstreet, T. Wheeler, H. Young, S Koenning, J. Mueller, R. Kemerait, and H. Mehl. 2014. Cotton variety and nematicide combinations for reniform and root knot management across the cotton belt. Beltwide Cotton Conf., LA Natl. Cotton Council, Cordova, TN. p. 295-301.

Mohotti, K.M., A.K. Prematunga, U.B. Herath, and P.G.D.S. Amarasena. 2018. New prophylactic nematicide for integrated nematode management in tea, $\mathrm{p}$. 10. In: T.L. Wijeratne and K.M. Mohotti (eds.). Proc. 235th Experiments and Extension Forum, New Pesticides for Integrated Pest Management in Tea. Tea Res. Inst. Sri Lanka, Talawakelle, Sri Lanka.

Patrignani, A. and T.E. Ochsner. 2015. Canopeo: A powerful new tool for measuring fractional green canopy cover. Agron. J. 107:2312-2320.

Sipes, B.S. and J.S. Lichty. 2002. Radopholus similis damage to Anthurium andraeanum. Nematropica 32:77-81.

Uchida, J.Y., B.S. Sipes, and C.Y. Kadooka. 2003. Burrowing nematode on anthurium: Recognizing symptoms, understanding the pathogen, and preventing disease. Univ. Hawaii Manoa, College Trop. Agr. Human Resour. Publ., Plant Dis. PD-24. 22 Apr. 2020. <https:// scholarspace.manoa.hawaii.edu/ bitstream/10125/12383/PD-24.pdf>.

U.S. Department of Agriculture and Hawaii Department of Agriculture. 2019. Hawaii horticulture and nursery products annual summary 2018. 13 July 2020. <https://www.nass.usda.gov/Statistics_ by_State/Hawaii/Publications/Flowers_ and_Nursery_Products/Floriculture/ 201909HawaiiWholeFlower.pdf>.

U.S. Environmental Protection Agency. 2011. Fenamiphos: Amendment to use deletion and product cancellation order. EPA Federal Register 76 FR 61690 (2011-25694). 11 May 2020. <https:// www.federalregister.gov/documents/ $2011 / 10 / 05 / 2011-25694 /$ fenamiphos-amendment-to-use-deletionand-product-cancellation-order $>$.

Vawa, O.S.T., G.P. Gnonhouri, S.P. Seri, A. Adiko, and A. Otchoumou. 2019. Evaluation de l'efficacite d'une formulation de fluopyram (velum prime) contre deux nematodes Radopholus similis et Pratylenchus coffeae, en culture de bananier en Cote d'ivoire. Agronomie Africaine 8:161-166.

Walker, J.T. and J.D. Wilson. 1960. The separation of nematodes from soil by a modified Baermann funnel technique. Plant Dis. Rep. 44:94-97.

Wang, K.-H., A.R. Kuehnle, and B.S. Sipes. 1997. In vitro screening for burrowing nematode, Radopholus similis, tolerance and resistance in commercial Anthurium hybrids. In Vitro Cell. Dev. Biol. 33:205-208.

Wang, K.-H., B.S. Sipes, and A.R. Kuehnle. 1998. In vitro tolerance and resistance to burrowing nematode, Radopholus similis, in Anthurium species. Euphytica 103:23-28. 